\title{
Can financial performance affect firm value?: mediated by dividend policy
}

\author{
Nurfala Safitri ${ }^{1)}$, Dinnul Alfian Akbar ${ }^{2)}$, Sri Delasmi Jayanti ${ }^{3)}$ \\ 1,2,3) The Faculty Of Islamic Economic And Business, UIN Raden Fatah Palembang \\ Corresponding author: dinnulalfiaanakbar_uin@radenfatah.ac.id
}

\begin{abstract}
This study aims to discover the effect of liquidity on firm value with dividend policy as the intervening variable in the manufacturing companies indexed by ISSI in the period of 2014-2018. In this study, we used 10 companies as samples. This study used quantitative research method. As for sampling technique, we used purposive sampling. The type of data is secondary data. Data analysis techniques used in this study were descriptive data analysis, classical assumption test analysis, multiple linear regression, whilst research hypotheses were tested by Eviews 9. The results showed that dividend policy did not mediate solvability effect on firm value, however dividend policy mediated the effect of liquidity on firm value.
\end{abstract}

Keywords: Solvability, Liquidity, Dividend Policy, Firm Value

\section{Introduction}

Indonesia has islamic population with a market share of $12.7 \%$ of the total muslim population of the world, therefore it has the potential to improve Indonesia's economy through the Islamic economy such as in the Islamic financial industry (Ihya Ulum Aldin, 2019). These opportunities will affect the Islamic capital market. One of the sharia capital market indices is the Indonesian Sharia Stock Index (ISSI).

ISSI is one of the stock indexes launched by the IDX on May 12, 2011. The existence of companies in ISSI is reselected twice a year, every May and November, following the DES review schedule (BEI, 2019). However, one sector that cannot be ignored is the manufacturing sector. The strength of the manufacturing industry lies in industrial products that can be traded by moving the value chain from producers to end consumers.

Investors as shareholders in investing their funds have the aim to maximize wealth through dividend policies that can be influenced by several factors such as solvability and liquidity summarized in the financial statements. According to Brigham and Houston, Liquidity is a ratio that shows the relationship between current assets and company cash and current liabilities. Liquidity can be used as a reference to see how far a company can finance its short-term obligations (Horne, James C. Van and John M. Wachowicz, 2014).

Meanwhile, according to Horne and Wachowicz that companies with large total debt will affect dividend policy, because if some of the profits are used to pay debts then the rest that will be used to pay dividends gets smaller (Horne, James C. Van and John M. Wachowicz, 2014).

This theory is supported by the phenomenon reported in Merdeka.com that one of the directors of stateowned companies in the aviation services sector stated that the company still has a debt burden of USD 754,207 million or around Rp 7.3 trillion. The debt burden is quite high, causing the company to not be able to share dividends from last year's net profit which reached around Rp 1.45 trillion. The company can only distribute dividends after the debt is paid. So, the distribution of company dividends will be realized if the debt is paid off (Merdeka.com).

The results of research from Asri Farida Sarah (2015), R. Ait Novatiani and Nur Annisa (2015) namely solvability affects dividend policy, whereas research conducted by Dwita Ayu Rizqia, et al (2013), Kumar (2007) shows that solvability has no effect towards dividend policy. The results of the study conducted by Marjam Mangantar (2019) showed that solvability affects corporate value, while the results of research conducted by Rara and Susanto (2018), Ilham and Acong (2017), indicate that solvability has no effect on firm value.

Research results from R.Ait Novatiani and Novi Oktaviani (2012), Suherli and Harahap (2004) show that liquidity affects dividend policy. Research by Nur Aqsho (2016) and Melati Puspa and Astrie Krisnawati (2012) show different results, namely liquidity has no effect on dividend policy. The results of research conducted by Risya Yusni Hudzaefa (2018) showed that liquidity affects the value of the company, while the results of research by Ilham and Acong (2017), and Alfredo Mahendra DJ (2011) showed that liquidity has no effect on Firm value. Research results from Jiang and Jiranyakul (2013), and Sri Sofyaningsih and Pancawati Hardiningsih (2011) stated that Dividend Policy influences Firm value, while the research by Amin Wijoyo (2012) and Wawan Cahyo Nugroho and Fadlil Abdani (2017) concluded that dividend policy does not affect firm value..

Based on the description above, this study is intended to examine more deeply regarding solvability, liquidity and dividend policies and its relation with the value of the company in the Islamic stock market. 


\section{Literature Review \\ Signaling Theory}

Signal theory states how a company actually gives signals to users of financial statements. This signal is in the form of information about what has been done by management to realize the owner's wishes. Signal theory is used to explain that basically financial statements are used to give positive and negative signals to the investors. (Brigham and Houstan, 2013).

In this case, dividend payments could be used as a signal for investors to describe a company's prospects in the future. In addition to the dividend policy, this study using signal theory as in Solvability. According to Signaling theory, solvability is a condition wherein the higher the level of a company's debt, it will enable the company to pay off its debt from the profits it gained. With the low debt of the company, the profits it derived also become higher, since it will paying lesser debts. This illustrated a condition in which the company's financial are good, therefore investors will trust the company. Investors will also assess that the company's prospects are good in the future and therefore, many investors would be interested into investing in it.

\section{Pecking Order Theory}

Pecking Order Theory in the analysis of capital structure which was developed by Myers and Majluf. Based on this theory, the main source of a company's capital has to be generated from the earning of its business operational in the form of net profits after tax which were not distributed to the owners of the company or shareholders (retained earnings). This retained earnings will be reinvested in a profitable business or company project. If retained earnings were not adequate to finance the profitable investment project, the company can also increase its capital by seeking funds from debt and then from equity or equity (Myers and Majluf, 1984).

The pecking order model arises due to the information asymmetry condition between the investors and the company. Therefore, there arises a corporate financing hierarchy which begins with retained earnings that has the lowest cost of information asymmetry, followed by debt, and finally equity or equity from external sources which has the highest cost of information asymmetry (Agus, 2011).

\section{Research Model}

Hypothesis, 1) Solvability influences dividend policy, 2) Liquidity influences divide policy, 3) dividend policy influences firm value, 4) solvability influences firm value, 5) liquidity influences firm value, 6) solvability influences firm value with dividend policy as the intervening variable, 7) liquidity influences firm value with dividend policy as the intervening variable.

\section{Research Method}

The population used in this study are all manufacturing companies indexed in the Indonesian Sharia Stock Index (ISSI) for the period of 2014 - 2018. In this study, samples were selected by using a purposive sampling method, the sampling is done in accordance with the research objectives set with secondary data obtained from the official site of the Indonesia Stock Exchange (IDX), www.idx.co.id. Application used in this research process is Ms. Excel 2010 and Eviews 9.

\section{Result and Discusssion}

Tabel 1. Partial Test of Solvability and Liquidity on Dividend Policy

\begin{tabular}{lccc}
\hline \multicolumn{1}{c}{ Variable } & Coefficient & t-Statistic & Prob. \\
\hline C & -17.61428 & -0.601909 & 0.5503 \\
\hline DER & 31.07002 & 4.838150 & 0.0000 \\
\hline CURRENT_RATIO & 0.091198 & 6.372556 & 0.0000 \\
\hline SU
\end{tabular}

Source : Output eviews 9.0 for windows

\section{Solvability Affects on Dividend Policy}

Solvability shows the alpha coefficient of $5 \%$ and t-statistics $4.838150>$ t-table 2.01410 prob. 0.0000 $<0.05$. Which means that Solvability influences and significantly affects Dividend Policy.

These results support the signaling theory where an increase in debt will affect the level of net income available to shareholders, which means the higher the company's liabilities, the lower the company's ability to pay dividends. The greater this ratio shows the greater the level of company dependence on external parties (creditors) and the greater the burden of debt costs to be paid by the company. An increase in debt basically will affect the size of the net profit available to shareholders including dividends to be received, because these obligations are higher, the company's ability to distribute dividends will be lower so that solvability affects the company's value. The results of the study are in line with the results of research results from Asri Farida Sarah (2015), R. Ait Novatiani and Nur Annisa (2015), namely solvability influences dividend policy. 
The validity test result indicates that the value of corrected item-total correlation $>$ r-table $(0.1829)$ or valid. Variable data in this study were tested and have a good reliability value with a significance level of 5\% and Cronbach's alpha based on STD. $>0.06$

\section{Liquidity Affects on Dividend Policy}

Liquidity shows the alpha coefficient of $5 \%$ and t-statistics $6.372556>$ t-table 2.01410 prob. $0.0000<0.05$ which means that the liquidity variable has an effect on and significant on the Dividend Policy.

The results of this study support the signaling theory which states that the state of a good financial statement can provide good information about dividend policy. Liquidity as part of a financial statement that illustrates the company's ability to pay short-term obligations / debt to outside parties. Liquidity is the company's ability to pay obligations / short-term debt to external parties. If related to dividend policy, liquidity is the company's ability to pay dividends to shareholders. The company considers that dividends are cash outflows that affect the company's cash flow position. This resulted in reduced opportunities for companies to make investments using cash distributed in the form of dividends. The more liquid a company is, the possibility of dividend payments made by the company will be even greater. Research results from R.Ait Novatiani and Novi Oktaviani (2012), Suherli and Harahap (2004) show that liquidity affects dividend policy.

Tabel 2. Partial Test of Solvability, Liquidity, and Dividend Policy on Firm Value

\begin{tabular}{lccc}
\hline \multicolumn{1}{c}{ Variable } & Coefficient & t-Statistic & Prob. \\
\hline C & -10.45545 & -0.396082 & 0.6940 \\
\hline DER & 22.22420 & 5.260893 & 0.0000 \\
\hline CURRENT_RATIO & 0.009811 & 0.857983 & 0.3957 \\
\hline DPR & 0.049876 & 1.044371 & 0.3021 \\
\hline
\end{tabular}

\section{Solvability Affects on Firm Value}

The solvability variable shows the alpha coefficient 5\% t-statistic 5.260893>t-table 2.01537 and prob. $0.0000<0.05$. Which means that the solvability variable has an effect on and significant to the Firm Value. This is consistent with the opinion of Modigliani and Miller in 1963 which states that if there is a corporate income tax then the use of debt will increase the value of the company because debt interest costs are costs that reduce tax payments (tax deductable expenses). With the reduction in tax payments, EAT (Earning After Tax) will increase and can increase the value of the company because profits will increase. The results of this study are in line with the results of research conducted by Marjam Mangantar (2019) explain that solvability influences firm value.

\section{Liquidity Affects on Firm Value}

The liquidity variable shows the alpha coefficient $5 \% \mathrm{t}$-statistic $0.857983<\mathrm{t}$-table 2.01537 and prob. $0.3957>0.05$. Which means the liquidity variable has no effect and is not significant to the Firm Value.

Based on the results of the study provide empirical evidence that liquidity has no effect on firm value. The results of this study are not in line with Signaling Theory which states that a high level of liquidity can give a signal to investors that the company's financial company is in good condition and can indicate the existence of liquidity that the company is able to finance its needs urgently, it can encourage the investors to invest in a company. The high interest of investors to invest can affect the increase in stock prices and the number of shares outstanding so that it can affect the value of the Price Book Value (PBV) of a company. The results of this study are in line with the results of research conducted by Ilham and Acong (2017), and Alfredo Mahendra DJ (2011) that liquidity has no effect on Firm value.

\section{Dividend Policy affects on Firm Value}

Dividend policy variables show the alpha coefficient 5\% t-statistics $1.044371<\mathrm{t}$-table 2.01537 and prob. $0.3021>0.05$ which means the dividend policy variable has no effect and is not significant to the Firm Value. The results of this study are not in line with the signaling theory which says that the market price and corporate value of a company can be influenced by dividend policy as a good signal to be received by investors. the theory of Franco Modigliani and Miller (MM) According to Modigliani and Miller that affects the value of the company is how much the company's ability to make a profit. While dividing profits into dividends and retained earnings does not affect the value of the company. The results of this study are in line with the research results of Amin Wijoyo (2012) and Wawan Cahyo Nugroho and Fadlil Abdani (2017) concluding that dividend policy has no effect on firm value.

\section{Mediation Variables \\ The Effect of Solvability on Firm Value with Dividend Policy as an Intervening Variable}

The multiple regression equation is the dependent variable Firm value (Y) on Solvability (X) and the intervening variable Dividend Policy $(Z)$. The analysis found that the dividend policy on the value of the 
company with a significance value of $0.0996>\alpha=0.05$ and the regression coefficient $(b)=0.062840$. Then found the direct effect ( $\mathrm{c}^{\prime}$ ) of 22.01974 which is smaller than $\mathrm{c}=22.21153$. The influence of solvability independent variables on the dependent variable is significant firm value $0.0000<\alpha=0.05$ after controlling for intervening variables dividend policy. It can be concluded that in this model there is no mediation, where solvability is not able to affect the value of the company directly or indirectly by involving the Dividend Policy or it can be said that the dividend policy does not mediate the relationship between Information Asymmetry and Corporate Value (unmediated).

\section{The Effect of Liquidity on Firm value with Dividend Policy as an Intervening Variable}

The multiple regression equation is the dependent variable Firm value $(\mathrm{Y})$ on the Independent Liquidity Variable (X4) and the intervening variable Dividend Policy (Z). The analysis found evidence that dividend policy has a positive and significant effect on firm value with a significance value of $0.0004<\alpha=0.05$ and regression coefficient $(b)=0.166475$. Furthermore, it was found the indirrect effect (c ') of -0.024232 which is smaller than $c=-0.005624$. The effect of the independent variable liquidity on the dependent variable firm value remains significant $0.0128<\alpha=0.05$ after controlling for intervening variables dividend policy. It can be concluded that in this model the dividend policy ( $\mathrm{Z}$ ) as a full mediating variable (Full Mediaton), where after entering the variable $\mathrm{Z}$, the effect of the variable $\mathrm{X}$ on $\mathrm{Y}$ which was not significant (before entering the variable $\mathrm{Z}$ ) becomes significant after entering the variable $\mathrm{Z}$ into the equation model regression.

\section{Conclusion}

The results show that Solvency affects the Dividend Policy, Liquidity affects the Dividend Policy, Profitability has no effect on Company Value, Solvency influences Company Value. Dividend policy does not affect the value of the company, dividend policy does not mediate solvability to firm value, dividend policy mediates liquidity to firm value.

\section{References}

Aldin Ihya Ulum, Indonesia Berpotensi Jadi Pemain Ekonomi Syariah Global, diakses pada 16 Oktober 2019 pukul 02:16 WIB dari https://katadata.co.id/berita/2018/07/25/indonesia-berpotensi-jadi-pemainekonomi-syariah-global.

DJ Alfredo Mahendra. 2011. Pengaruh Kinerja Keuangan terhadap Nilai Perusahaan (Kebijakan Deviden sebagai Variabel Moderasi) pada Perusahaan Manufaktur di Bursa Efek Indonesia.

Horne, J. C. V., \& John M. Wachowicz, Jr. 2014. Prinsip-prinsip Manajemen Keuangan. Jakarta : Salemba Empat.

Jiang \& Jiranyakul. 2013. Capital Structure, Cost of Debt and Dividend Payout of Firms in New York and Shanghai Stock Exchanges. International Journal of Economics and Financial Issues Vol. 3, No. 1, 2013, pp.113-121 ISSN: 2146-4138 www.econjournals.com.

Kumar Suwendra. 2007. Analisis pengaruh Struktur Kepemilikan, Investment Opportunity Set (IOS), dan Rasio-Rasio Keuangan Terhadap DPR, Semarang : Program Pasca Sarjana Magister Manajemen Universitas Diponegoro

Lumentut Faldy G. \& Mangantar Marjam. 2018. Pengaruh Likuiditas, Profitabilitas, Solvabilitas, Dan Aktivitas Terhadap Nilai Perusahaan Mannufaktur Yang Terdaftar Di Indeks Kompas100 Periode 20122018. Jurnal EMBA Vol.7 No.3 Juli 2019, Hal. 2601 - 2610.

Merdeka.com, Utang belum lunas, Garuda Indonesia tak bagi dividen, https://www.merdeka.com/uang/utang-belum-lunas-garuda-indonesia-tak-bagi-dividen.html. diakses pada 22/12/2019 di Palembang.

Novatiani R. Ait \& Oktaviani. Novi. 2012. Pengaruh Profitabilitas, Likuiditas, Leverage dan Ukuran Perusahaan Terhadap Kebijakan Dividen Pada Perusahaan Manufaktur Di Sektor Industri Barang Konsumsi Yang Tedaftar Di Bursa Efek Indonesia. Universitas Widyatama Bandung.

PT Bursa Efek Indonesia, Indeks Saham Syariah, diakses pada 20 September 2019 Pukul 08.20 WIB di Palembang dari https://www.idx.co.id/idx-syariah/indeks-saham-syariah/.

Rizqia Dwita Ayu dkk. 2013. Effect of Managerial Ownership, Financial Leverage, Profitability, Firm Size, and Investment Opportunity on Dividend Policy and Firm Value, Research Journal of Finance and Accounting www.iiste.org ISSN 2222-1697 (Paper) ISSN 2222-2847 (Online) Vol.4, No.11. 